DANMARKS GEOLOGISKE UNDERS ØGELSE

II. RAEKKE. NR. 93

GEOLOGICAL SURVEY OF DENMARK. II. SERIES. NO. 93

\title{
The Lower Cambrian from \\ Slagelse no.1, Western Sealand
}

\author{
By \\ Chr. Poulsen \\ Dansk sammendrag: \\ Nedre Kambrium i Slagelse no. 1, Vestsjælland
}

I kommission hos

C. A. REITZELS FORLAG

KØBENHAVN 1969 
DANMARKS GEOLOGISKE UNDERSØGELSE

II. RÆKKE. NR. 93

Geological Survey of Denmark. II. Series. No. 93

\title{
The Lower Cambrian from \\ Slagelse no.1, Western Sealand
}

\author{
By \\ Chr. Poulsen \\ Dansk sammendrag: \\ Nedre Kambrium i Slagelse no. 1, Vestsjælland
}

I kommission hos

C. A. REITZELS FORLAG

KøBENHAVN 1969 
With 1 plate 


\section{CONTENTS}

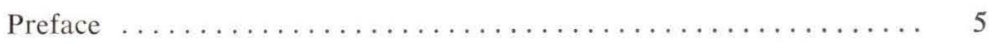

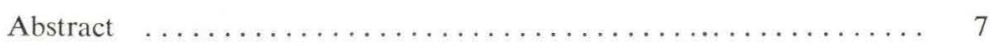

Introduction $\ldots \ldots \ldots \ldots \ldots \ldots \ldots \ldots \ldots \ldots \ldots \ldots \ldots \ldots \ldots \ldots \ldots, \quad 9$

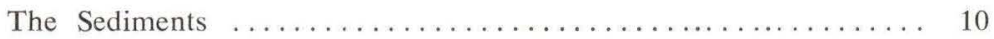

Descriptions of the Fossils ....................... 12

Stratigraphic Position and Correlation of the Sediments ........ 20

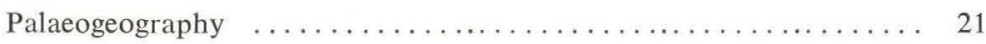

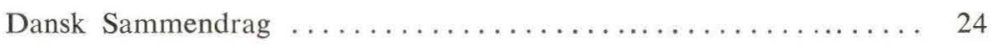

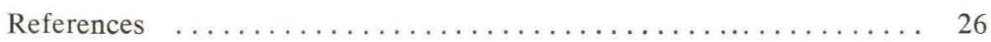

Plate ....................................... 29 


\section{PREFACE}

In a report of 1964, "Deep Tests in Denmark 1935-1959" (Geological Survey of Denmark, 3. ser., no. 36), Professor Theodor SorgenfreI, Ph. D., of the Technical Highschool of Denmark and Arne Buch, M. Sc., of the Geological Survey of Denmark published brief descriptions of material originating from a considerable number of boreholes in Denmark and presented an important outline of the pre-pleistocene stratigraphy of the country. In a locality $4.4 \mathrm{~km}$ SSE of Slagelse City and $700 \mathrm{~m} \mathrm{~N}$ of Harrested village, referred to as Slagelse no. 1, (D.G.U. File No. 215. 257), drilling penetrated to a depth of $2973.30 \mathrm{~m}$ below the ground. The lowermost $390.30 \mathrm{~m}$ of the strata were referred to the Lower Palaeozoic.

The writer is much indebted to the Director of the Geological Survey of Denmark, Dr. O. Berthelsen, who placed the Lower Palaeozoic material from Slagelse at his disposal for study and publication. Special thanks are due to Dr. L. Banke Rasmussen and Arne Buch, M. Sc., of the Geological Survey of Denmark for important supplementary information. All figures in the plate accompanying this paper are photographs taken by the writer; the prints have been made with great care and ability by Mr. P. Nielsen of the Mineralogical-geological Institutes of the University of Copenhagen. 


\begin{abstract}
The material described and discussed in the present paper originates from a deep borehole near Slagelse on western Sealand. Quartzitic beds, probably belonging to the Mobergella holsti zone, are followed by silty shale with Lower Cambrian fossils. The fauna is represented by the following genera and species: Parahyolithes danicus n. g. et n. sp., Kjerulfia selandica n. sp., Holmia kjerulfi (Linnarsson)?, Ellipsostrenua conifrons n. sp., Torellella holmi Kier, Torellella laevigata (LinNarsson), and indeterminable fragments of olenellid trilobites. The fossiliferous silty shale is referred to the Holmia kjerulfi zone. Finally, the eventual palaeogeographic significance of the material is discussed.
\end{abstract}




\section{INTRODUCTION}

As mentioned in the preface SorgenfreI and Buch (1964) referred about $390 \mathrm{~m}$ of the penetrated strata at Slagelse to the Lower Palaeozoic.

The interval referred to the Ordovician-Silurian was classified by these authors partly by means of its graptolites. This series of strata was characterized as follows:

“2583-2917 m. Ordovician-Silurian.

2583-2626 m. Limestone, grey, and shale, dark grey, thinly laminated. Dip 6-7 ${ }^{\circ}$. Graptolithes.

2626-2637 m. Claystone, dark red, silty, non calcareous.

2637-2917 m. Shale, dark grey, beds of siltstone, light grey. Dip $16^{\circ}$ ? $-24^{\circ}-30^{\circ}-40^{\circ}$. 2768-2774 m.: Dictyonema sp., 2810-2812 m.: Monograptus crispus LAPwORTH". ${ }^{1}$

Sorgenfrei and Buch (1964) described the interval 2917-2972 m. as follows:

"2917-2944 m. Cambrian. Shale, black, pyritic, with spindle-shaped baryte crystals, "Alum shale". Dip 10-120".2

“2944-2966 m. Shale, dark grey, hard. Dip 20.

2966-2972 m. Lower Cambrian or Eocambrian. Sandstone, quartzitic, light grey. Dip $22^{\circ}$ ?"3

1. It appears from this brief description that the interval $2583-2812 \mathrm{~m}$ can be referred safely to the Silurian. On the other hand the age of strata between 2812 and $2917 \mathrm{~m}$ is uncertain owing to lack of palaeontological evidence; by their lithological character, however, they are united with the overlying Silurian strata, and, accordingly, the presence of Ordovician strata in this interval is rather questionable.

2. In the Scandinavian-Baltic region the lowermost Ordovician, the Dictyonema shale, is developed as alum shale; it is therefore pessible that part of the black shale may be of early Ordovician age.

3. According to the list of cores received from the Geological Survey of Denmark the lower end of the quartzite core originates from a depth of $2973.3 \mathrm{~m}$. 
In material from the interval 2944-2966 m. the present writer succeeded in finding a few Lower Cambrian fossils which are described in the following in addition to brief descriptions of these strata and the subjacent quartzitic sandstone.

\section{THE SEDIMENTS}

Unfortunately, the rocks of the interval 2944-2973.3 m. are known mainly from wash material consisting of so small pieces that eventual small fragments of fossils easily escape observation. From the dark grey, hard shale between 2944 and 2966 m., however, a core (no. 14) with Lover Cambrian fossils, covering the interval 2957-2958 m., was obtained.

The subjacent quartsitic strata between 2966 and 2973.3 are represented by core no. 15, covering the interval $2971.8-2972.1 \mathrm{~m}$., and core no. 16 from 2972.6 down to $2973.3 \mathrm{~m}$.

The following brief descriptions of the sediments are based on thin sections originating from the mentioned cores.

Core no. 14:

2957.00-2957.01 m. Shale dark grey, moderately hard, silty, consisting of of densely crowded grains of quartz and sparse grains of glauconite in a very fine-grained, non calcareous matrix. The diameters of the quartz grains vary from 0.03 to $0.1 \mathrm{~mm}$., the former category strongly predominant. The glauconite grains are of the same sizes as the quartz grains. In the matrix regularly rounded grains measuring $0.006 \mathrm{~mm}$. are strongly predominant and accompanied by still smaller particles of irregular shape. All grains of quartz and glauconite are angular. A few indeterminable fragments of fossils have been observed.

2957.01-2958.00 m. Coarse siltstone, dark grey, hard, somewhat shaly, consisting of closely crowed, angular grains of quartz and sparse grains of glauconite in an exceedingly finegrained matrix. The diameters of the quartz grains vary from 0.03 to $0.09 \mathrm{~mm}$., the former category strongly predominant. The glauconite grains are of the the same sizes as the quartz grains. The non calcareous matrix is formed by grains of the size of clay particles. Phosphorite occurs at the $2957.62 \mathrm{~m}$. level partly as 
irregular, rounded nodules measuring up to $20 \mathrm{~mm}$. in diameter, partly as small angular fragments. Fossils have been observed at the following levels:

2957.02 m: Ellipsostrenua conifrons n. sp.

2957.03 m: Holmia kjerulfi (LinNARSSON)?

2957.12 m: Parahyolithes danicus n. g. et n. sp. and indeterminable olenellid fragments.

2957.40 m: Torellella holmi KIAER and indeterminable olenellid fragments.

2957.45 m: Torellella laevigata LiNNARSSON and indeterminable olenellid fragments.

$2957.50 \mathrm{~m}$ : Kjerulfia selandica n. sp.

$2957.55 \mathrm{~m}$ : Indeterminable olenellid fragment.

$2957.57 \mathrm{~m}$ : Indeterminable olenellid fragment.

2957.77 m: Holmia kjerulfi LinNARSSON?

2957.80-2957.90 m: Indeterminable olenellid fragments.

Core no. 15:

2971.80-2971.85 m. Mudstone, dark grey, much silty, non calcareous. The grains of the silty constituent, mainly quartz, are angular, and most frequently with diameters about $0.015 \mathrm{~mm}$.

2971.85-2972.00 m. Quartzite, light grey. About 70 per cent of the quartz grains vary from 0.2 to $0.5 \mathrm{~mm}$. in diameter, about 27 per cent from 0.5 to $1.0 \mathrm{~mm}$., and about 3 per cent surpass $1 \mathrm{~mm}$. Glauconite grains have been observed, but they are extremely rare. Minute crystals of pyrite occur dispersedly.

2972.00-2972.10 m. Mudstone, dark grey, silty, somewhat shaly, non calcareous. The grains of the silty constituent, mainly quartz, are angular, small, rarely surpassing $0.015 \mathrm{~mm}$. in diameter.

Core no. 16:

2972.60-2973.30 m. Quartzite, light grey, highly reminiscent of that of core no. 15, yet with coarser grains. About 50 per cent of the grains vary from 0.2 to $0.5 \mathrm{~mm}$. in diameter, about 30 per cent from 0.5 to $1.0 \mathrm{~mm}$., and about 20 per cent surpassing $1 \mathrm{~mm}$. Glauconite not observed. Minute crystals of pyrite occur dispersedly. 


\title{
DESCRIPTIONS OF THE FOSSILS
}

\author{
Phylum Mollusca \\ Class Calyptoptomatida FisHer, 1962 \\ Order Hyolithida MatTHew, 1899 \\ Suborder Hyolithina MatThEw, 1899 \\ Family Sulcavitidae Syssoiev, 1958? \\ Genus Parahyolithes n. g.
}

(Type species Parahyolithes danicus n. sp.)

Diagnosis: Shell straight, with flat ventral side, moderately projecting ventral lip, and surface markings consisting of regularly spaced lines of growth crossed by regularly spaced longitudinal ribs so as to form a regular net-work with tiny nodules where the growth lines are crossed by the ribs.

Remarks: Parahyolithes is distinguished from other genera of the family Sulcavitidae by its regularly reticulate shell surface. The surface markings resemble those of an Ordovician species described and figured by HoLm under

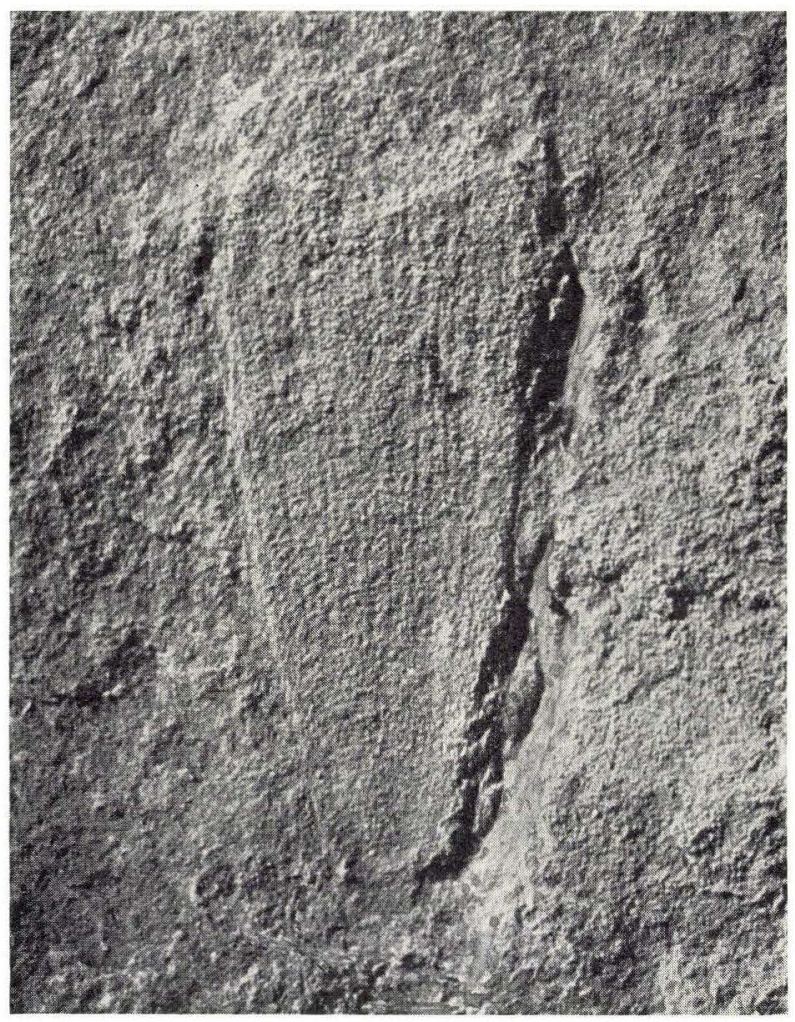

Fig. 1. Parahyolites danicus n. g. et n. sp., ventral side, $\mathrm{x} 8$. 
the name of "Hyolithus (Orthotheca) trinucleorum" (HoLm, 1893, p. 67, pl. 5, figs. 79-87), but the pattern of the type and only known species of Parahyolithes differs from that of HoLM's species in having evenly curved growth lines corresponding to the curvature of the projecting ventral lip, and, accordingly, Parahyolithes has nothing to do with the Ortothecidae.

\section{Parahyolithes danicus n. sp. \\ Pl., fig. 8, text-fig. 1.}

Material: One fragmentary specimen, showing the greater part of the ventral side.

Level: $2957.12 \mathrm{~m}$. below the ground.

Description: Shell straight, tapering towards the posterior end at an increasing rate, with flat ventral side and moderately projecting ventral lip. Apical angle estimated to be about $35-40^{\circ}$. External surface marked by regularly spaced lines of growth of equal strength, spaced about 8 to the millimetre, and about 20 regurlarly spaced longitudinal ridges of equal strength, spaced about 4 to the millimetre in the anterior part of the specimen; these surface markings form a reticulate pattern with tiny modules where the growth lines are crossed by the ridges.

Phylum Euarthropoda

Subphylum Trilobitomorpha STøRMER, 1944

Class Trilobita WALCH, 1771

Order Redlichiida RICHTER, 1933

Suborder Olenellina Resser, 1938

Family Olenellidae Vogdes, 1893

Subfamily Callaviinae Poulsen, 1959

Genus Kjerulfia KIÆR, 1917

Kjerulfia selandica n. sp.

Pl., figs. 1-2.

Material: One somewhat fragmentary cephalon.

Level: $2957.50 \mathrm{~m}$. below the ground.

Diagnosis: A Kjerulfia with very wide extraocular genal region and narrow cephalic border.

Description: Cephalon about twice as wide as long (estimated), semicircular in outline (estimated). Glabella outlined by shallow axial furrow, about 1.7 times as long as wide, occupying about one-fourth the width of cephalon, somewhat tapering posteriorly. Frontal lobe narrow, occupying about half the length of glabella, tapering to a narrowly rounded front. 
Lateral glabellar lobes defined by 3 narrow, slightly oblique transglabellar furrows which are deeply impressed at sides and moderately so in the middle of glabella. Occipital furrow narrow, deeply impressed throughout, connected with the preoccipital transglabellar furrow by a wide, shallow median depression. Occipital ring narrow (sag.), of about the same width (trans.) as posterior part of glabella, subdivided by a shallow intraoccipital furrow into anterior and posterior band, the latter carrying a minute mesial tubercle very close to posterior margin. Palpebral lobes long, strongly curved, terminating opposite to occipital furrow fairly close to axial furrow, their outer margin almost forming a semicircle; anterior portion of palpebral lobes and palpebral furrows crossed by the shallow axial furrow, their proximal ends gradually merging into the frontal lobe well inside the axial furrow. Extraocular genal region very wide. Border furrow shallow, faintly marked. Border very narrow, flat; posterior margin almost perpendicular to the sagittal line for the greater part of its length, distally curved so as to form a small notch just inside short, rapidly tapering genal spines. Surface markings consisting of extremely delicate, inosculating ridges, forming a net-work with practically microscopic meshes; on the cephalic border the meshes are oblong, forming a system of subparallel lines.

\section{Dimensions:}

Lenght of cephalon at sagittal line ............ about $12-13 \mathrm{~mm}$. (estimated)

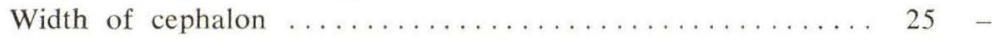

Length of glabella ..................... 10 -

Width of glabella across frontal lobe .............. 4.5 -

Width of glabella at anterior lateral glabellar lobe $\ldots \ldots \ldots \ldots 66$ -

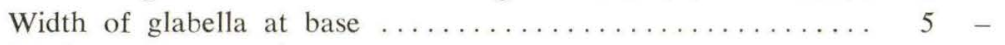

Maximum distance between eyes ................ 14 -

Remarks: Kjerulfia selandica has several characters in common with the type species, Kjerulfia lata KIÆR, for instance the pearshaped frontal lobe, the tiny tubercle on the posterior band of the occipital ring, the median depression connecting the occipital furrow with the preoccipital transglabellar furrow, and the long, strongly curved palpebral lobes; it differs from the type species in having narrow cephalic border, a notch in the posterior cephalic margin just inside the genal spines, much wider extraocular genal region, and frontal lobe much narrower than the adjacent portion of glabella.

The type species has for a long time been regarded as the only known certain species of the genus Kjerulfia. Accordingly, the find of another species must give rise to a revision of the generic diagnosis. In spite of the mentioned differences between Kjerulfia lata and the species described above the writer is of opinion that the shape of the glabella, especially the pearshaped frontal lobe and the shallow median depression connecting the 
occipital furrow with the preoccipital transglabellar furrow ${ }^{1}$ are important features which idicate that they are bound up with each other.

KIÆR (1917, p. 73) discussed the possibility of including the Scanian species described and figured by Moberg (1899, p. 321-329, pl. 14) as "Holmia lundgreni" in the genus Kjerulfia. The present writer has studied MoberG's material and arrived at the conclusion that at least two genera are represented, but, as emphasized by KIÆR (1917, p. 73) more complete material must be collected before these fragments can be determined with certainty. Nevertheless a few suggestions concerning Moberg's "Holmia lundgreni" are introduced in the following as a modest contribution to the discussion.

The present writer (1958, p. 16) has called attention to the fact that species of the genus Wanneria WALCOTT have metagenal angles remote from the occipital ring, i. e. nearer to the genal angles than to the occipital ring, a character which serves to distinguish cephala of Wanneriinae from those of the Holmiinae. Judging from this character the cephalon represented by MoberG's pl. 14, fig. 4 belongs probably to the genus Holmia MATTHEw, whereas the cephalon represented by pl. 14, figs 2 a-b may be referable to Wanneria. SchwarzBach (1939, p. 772-773, pl. 50, figs. 3-7) has described a Lower Cambrian trilobite from Upper Lusatia under the heading "Wanneria cf. walcottana"; the present writer is convinced that this material represents a true Wanneria and even a species which must be very closely related to the type species, Wanneria walcottana (WANNER). This genus was formerly known only from North America, Greenland, and Great Britain. After Schwarzbach's find of a true Wanneria in Silesia the possibility that the specimens represented by MoBerG's pl. 14, figs. 1, $2 \mathrm{a}-\mathrm{b}, 6$, and 14 may be referable to Wanneria should be taken seriously into consideration. The Lower Cambrian blue clay and Eophyton sandstone of Esthonia deserves also notice in this connection. Smidtiellus mickwitzi (SCHMIDT, 1888) was for many years the only recognized olenellid of the Esthonian Lower Cambrian. This view, which was questioned by ÖPIK (1925), was also maintained by JANISCHEWSKy (1927), whereas SchINDEWOLF (1927) published a reconstruction which differs strongly from ScHMidT's figures, and the name Schmidtiellus was replaced by Holmia. The differences between SCHMIDT's figures and SCHINDEWOLF's reconstruction are so striking that the occurence of more than one olenellid genus in the Esthonian Lower Cambrian

1. The existence of such median depression in Kjerulfia lata appears from fairly well preserved specimens figured by KIÆR (1917, pl. 9, figs. 2-4 and pl. 10, fig. 1).

Such median depression is also visible in Kjerulfia? granulata RAw (1936, pl. 20, figs. $4 \mathrm{a}-\mathrm{b})$ which differs from Kjerulfia lata in having much narrower extraocular genal region, but apart from this difference RAw's species has many characters in common with Kjerulfia lata, and it should probably be regarded as a true Kjerulfia. 
is clearly indicated. Accordingly, a restudy of the Esthonian material is desirable. The present writer has never had the opportunity of studying the material in question, but, as a result of an examination of ScHMidT's and JANISCHEWSKY's figures, a few hints may be presented here. The genus Schmidtiellus (type species Olenellus mickwitzi ScHmidT, 1888) may be maintained to cover the specimen represented by SснміDT 1888, pl. 1, figs. 4 a-b (= JANISCHEWSKY 1927, pl. 4, fig. 7) and JANISCHEWSKY 1927, pl. 5, figs. 1a-b. The occurrence of the genus Holmia in the Lower Cambrian of Esthonia is suggested by the cephalic fragment figured in JANISCHEWSKY's pl. 4 , fig. 1 and by the pygidium in JANISCHEWSKY's pl. 4, fig. 6 , whereas the librigena represented by his pl. 4, fig. 10 (= SснмIDT 1888, pl. 1, fig. 7 a) may be referable to Wanneria.

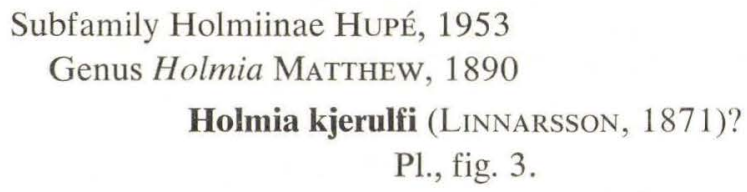

(For synonymy see WaLCOTT 1910, p. 288)

Material: two fragmentary glabellae.

Level: 2957.03 and $2957.77 \mathrm{~m}$. below the ground.

Remarks: The very fragmentary state of preservation is the main reason why the material is determined with reservation. The figured fragment agrees clearly with Holmia kjerulfi as figured by KIÆR (1917) in having strongly expanded frontal lobe, and first lateral glabellar lobe extended laterally beyond second lateral glabellar lobe and curved strongly backwards distally with a tendency to embrace the distal portion of the latter. The palpebral lobe of the figured specimen, however, appears to be less prominent than in the specimens figured by KIÆR (1917), but this may be related to deformation by pressure; the other specimen in hand is more normal in this respect.

Subfamily and genus uncertain Pl., figs. 4-5.

Material: A fragment of a large cephalon, showing a little more than right half of the glabella (exclusive of frontal lobe) and adjacent part of the genal rigion.

Level: $2957.57 \mathrm{~m}$. below the ground.

Description: Cephalon almost flat. Glabella apparently wide, almost flat, divided by wide shallow furrows the two anterior of which are transglabellar and extremely shallow, whereas the posterior one is effaced in the middle of glabella. Occipital furrow wide and shallow. Occipital ring very wide 
(sag.), as flat as the preoccipital segment, apparently without mesial tubercle. Axial furrows extremely shallow, parallel from posterior cephalic margin to posterior glabellar furrow, then diverging abruptly so as to indicate a very considerable expansion of the anterior part of the glabella, and becoming almost effaced in front of second lateral glabellar lobe. Palpebral lobes practically on a level with adjacent part of fixigenae, moderately and evenly curved, terminating posteriorly a little beyond occipital furrow. Palpebral furrow very shallow, almost effaced. Posterior border narrow, slightly convex, defined by very shallow posterior border furrow.

Remarks: The specimen described above is remarkable for its flatness and considerable size; the total length of cephalon is estimated to have been about $50 \mathrm{~mm}$.; it may represent a new species and even a new genus, but the fragmentary state of preservation does not allow of any safe decision.

\author{
Suborder Redlichiina Harrington, 1959 \\ Superfamily Ellipsocephalacea MAтTHEW, 1887 \\ Family Ellipsocephalidae MatrHew, 1887 \\ Subfamily Ellipsocephalinae MatThew, 1887 \\ Genus Ellipsostrenua KaUtsKy, 1945
}

\title{
Ellipsostrenua conifrons n. sp.
}

$$
\text { Pl., figs. 6-7. }
$$

Material: A slightly deformed cranidium.

Level: $2957.02 \mathrm{~m}$. below the ground.

Diagnosis: An Ellipsostrenua with strongly tapering, anteriorly truncate glabella.

Description: Cranidium 1.22 times as wide as long, subrectangular in outline, moderately arched longitudinally and transversally ${ }^{1}$. Glabella defined by wide, shallow axial furrows, occupying about 0.7 of cranidial length and 0.47 of width, 1.2 times as long as wide, considerably tapering, truncate in front, separated from anterior border by wide, very shallow preglabellar furrow, distinctly elevated above fixigenae, with 3 pairs of oblique, almost effaced lateral glabellar furrows. Occipital furrow narrow, deeply impressed throughout. Occipital ring moderately wide (sag.), narrowing towards axial furrows. Anterior and palpebral areas of fixigenae almost as wide as base of glabella; eye-ridges oblique, almost effaced; palpebral lobes long, narrow, rising opposite to anterior pair of lateral glabellar furrows, curved backwards at an increasing rate to terminate at posterior border furrow; posterior areas of fixigenae extremely narrow (trans.), divided by wide, well impressed border furrow into subequal portions. The course of anterior and posterior

1. The convexity of the cranidium has probably been somewhat reduced by pressure. 
sections of facial suture approximately parallel to sagittal line. Anterior border furrow wide, extremely shallow, almost effaced, paralleling the moderately curved anterior cranidial margin. Anterior border moderately wide, flat, horizontal.

\section{Dimensions:}

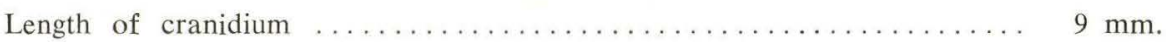

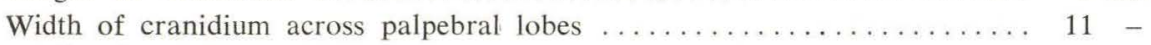

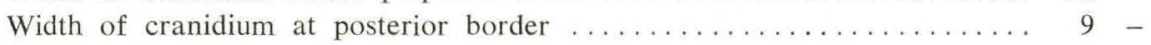

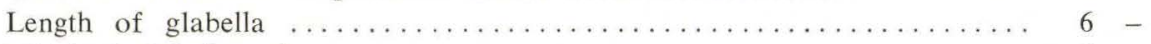

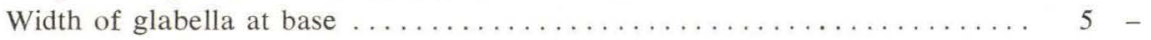

Width of glabella at anterior end of palpebral lobes . . . . . . . $3 \ldots \ldots \ldots$

Remarks: To the writers knowledge the type species (Strenuella (Ellipsostrenua) gripi KAUTSKY) and the species described above are for the present the only known species of the genus Ellipsostrenua.

\section{FOSSILS OF DOUBTFUL TAXONOMIC AFFINITY}

Family Torellellidae HoLm, 1893

The genus Hyolithellus Billings was referred to the Pogonophora by V. Poulsen (1963) who called attention to several points of resemblance e. g. the relatively high content of calcium, nickel, and zinc in the tubes. Furthermore, x-ray fluorescence analysis of extraordinarily well-preserved tubes of Hyolithellus also shows that no phosphorus is present. It deserves notice in this connection that the tubes of Hyolithellus and those of the recent Pogonophora have many amino acids in common, i. a. Alanin. ${ }^{1}$ Finally, the find of very long tubes of Hyolithellus micans BILlings (KAUTSKY 1945) must be regarded as an important supplement to the evidence which favours the reference of Hyolithellus to the Pogonophora.

The Torellellidae was tentatively placed together with the Hyolithellidae in one and the same order by V. Poulsen (1963) and D. W. Fisher (1962). The present writer, however, hesistates to accept this view without further ceremony. Torellella differs from Hyolithellus and other Pogonophora in having much shorter tube with elliptical or biconvex lens-shaped cross section.

1. Written communication from Dr. David B. Carlisle of the Anti-Locust Centre. London. 
Genus Torellella HoLm, 1893

Torellella holmi KIÆR, 1917

Pl., fig. 9.

1917. Torellella laevigata LiNNARSSON var. holmi KIÆR, Videnskapsselskapets Skrifter, I, Mat.-Naturv. Klasse, no. 10, p. 20-24. - Christiania. Material: One almost complete specimen.

Level: $2957.40 \mathrm{~m}$. below the ground.

Remarks: KIER (1917, p. 24) compared the material from the locality Tømten with the type species (Hyolithes laevigatus LinNarsson, 1871) ${ }^{1}$ and concluded that "with our existing and still very imperfect knowledge of Torellella laevigata LNRS. there does not appear, however, to be any reason for separating the Tømten form as a new species, as LinNARSSON's species differs considerably within the limits given to it by HoLM - - - I therefore place the form from Tømten as a new variety, which I name var. Holmi - - -". KIÆR (1917, p. 24), however, also states that "If we compare this with HoLM's description of the typical Torellella laevigata LNRS. it will be seen that the Tømten form differs from the former in several respects. The shell is larger, more regular, straighter, and has a rounder section". Unfortunately, KIÆR's specimens from Tømten are as a rule highly flattened; only one fragment from sandy limestone has avoided compression and shows "a considerably rounder section than that given by HoLm for Torellella laevigata" (KIER 1917, p. 24). In the present writers opinion the fact that the shell is larger, more regular, straighter, and has a rounder section is in favour of regarding the Tømten form as an independent species - not a variety of Torellella laevigata.

The specimen from Slagelse agrees with KIÆRs description and is perfectly conformable to the Norwegian specimen represented by KIÆR's pl. 3, fig. 5 .

\section{Torellella laevigata (LiNNARSSON, 1871)}

1871. Hyolithus laevigatus Linnarsson, K. Vet. Akad. Handl., vol. 9, no. 7, p. 147, pl. 1, figs. 1-6. - Stockholm.

1893. Torellella laevigata Holm, Sveriges Geol. Unders., ser. C, no. 112, p. 147, pl. 1, figs. 1-6. - Stockholm.

Material: A couple of fragments.

Level: $2957.45 \mathrm{~m}$. below the ground.

1. It is important in this connection to call attention to the fact that in 1962 FISHER (Treatise on Invertebrate Paleontology, vol. W, p. 131, figs. 3a-c) by mistake has figured the Ordovician Torellella taenia HoLm under the name of "Torellella laevigata (LINNARSSON)". 
Remarks: The specimens in hand are very fragmentary, but they show the usual thin, black, phosphatic shell and a cross section similar to those figured by Holm (1893, pl. 1, figs. 2 and 6).

\section{STRATIGRAPHIC POSITION AND CORRELATION OF THE SEDIMENTS}

The Lower Cambrian age of the dark grey, silty shale (core no. 14) appears clearly from the fauna, which contains olenellid trilobites. The occurence of Holmia kjerulfi LINNARSSON? and Torellella holmi KIÆR indicates that this sediment should probably be referred to the Holmia kjerulfi zone. Fossils have not been observed in the wash material from the intervals above and below the core, and accordingly, the theoretical possibility that the dark grey, silty shale may include other zones than that of Holmia kjerulfi must be mentioned; hence the question-marks in the correlation table.

\begin{tabular}{|c|c|c|c|}
\hline \multicolumn{4}{|c|}{ CORRELATION TABLE } \\
\hline \multirow{9}{*}{ 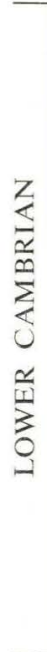 } & & SCANIA $^{1}$ & SLAGELSE \\
\hline & Zones & Lithologic divisions & \\
\hline & $\begin{array}{l}\text { Strenuella (Comluella) } \\
\text { linnarssoni }\end{array}$ & $\begin{array}{l}\text { Arenaceous limestone, or light shale, } \\
\text { or dark sandstone }\end{array}$ & $?$ \\
\hline & Holmia kjerulfi & Grey shale (greywacke) & $\begin{array}{l}\text { Dark grey, } \\
\text { silty shale }\end{array}$ \\
\hline & Holmia torelli and & $\begin{array}{l}\text { Coarse quartz sandstone } \\
\text { (»Rispebjerg sandstone «) }\end{array}$ & \multirow{2}{*}{ ? } \\
\hline & Wanneria lundgreni & $\begin{array}{l}\text { Calcareous, phosphatic, and } \\
\text { glauconitic sandstone }\end{array}$ & \\
\hline & \multirow[t]{2}{*}{ Mobergella holsti } & $\begin{array}{l}\text { Sandstone with Diplocraterion, } \\
\text { Skolithos, etc. }\end{array}$ & $\begin{array}{l}\text { Slagelse } \\
\text { quartzite }\end{array}$ \\
\hline & & Hardeberga sandstone (s. s.) & $?$ \\
\hline & Non-fossiliferous & Arkose, in places with conglomerate & $?$ \\
\hline
\end{tabular}

1 Mainly after REgnéLl (1960).

The stratigraphic position of the Slagelse quartzite is much more problematic. This rock is devoid of fossils. Lithologically it agrees perfectly with the upper part of the Balka quartzite of the island of Bornholm, and accordingly, it has been placed in the correlation table as a stratigraphic equivalent of the Balka quartzite i. e. corresponding to the Mobergella holsti 
zone of Sweden. The formation of both quartzites is regarded as a result of weathering of Precambrian crystalline rocks. The quartz grains of the Balka quartzite originate from the Precambrian gneiss and granite of the island of Bornholm, whereas those of the Slagelse quartzite probably was derived from the Precambrian gneiss ridge, which extends from the Ringk $\varnothing$ bing Fjord region of western Jutland to the island of Funen and probably formed the south-western coast of the Danish embayment during the early Cambrian. Nevertheless there is no proof that the sedimentation of the Slagelse quartzite took place at the same time as that of the Balka quartzite, but the writer is of opinion that in all probability both quartzites were deposited during one and the same stage of early Cambrian marine transgression.

\section{PALAEOGEOGRAPHY}

In a recent paper STøRMER (1967) emphasized the palaeogeographic importance of the subsiding intracratonic basin, which extended from the Oslo region to Scania, Poland, and the Baltic Soviet Republics, the so-called Oslo-Scania-Baltic syneclise. The very existence of the Slagelse quartzite indicates the presence of a Precambrian land surface consisting of weathering gneiss or granite near the basin in which the quartzite was deposited. It is an obvious conclusion that the quartz grains of the Slagelse quartzite originate from the Ringk $\varnothing$ bing-Funen gneiss ridge, which may have played an important part as a threshold, forming the south-western coast of the early Cambrian sea in the Oslo-Scania-Baltic syneclise. This view is to some extent confirmed by the geographical distribution of the olenellid genus Wanneria. Wanneria is a typical member of the olenellid fauna of the appalachian region where it is associated with the genera Olenellus and Paedeumias. These three genera are also found in the Caborca region of Mexico, and further in East Greenland and North Greenland. In 1947 the writer studied the Lower Cambrian fauna of north-western Scotland and was able to establish the fact that in addition to Olenellus this fauna also contains Paedeumias and Wanneria. The Cambro-Ordovician of north-western Scotland has many striking points of resemblance to that of the appalachian region and East Greenland, and, assuming that continental drift has taken place, the mentioned scottish region might be explained as a "missing link", filling part of the space between the appalachian and the East Greenland geosynclines; this would account for the occurence of Cambro-Ordovician of American type on the eastern side of the Atlantic (C. Poulsen 1951). The genus Wanneria, however, has been able to leave its typical realm and penetrate far eastward into northern Central Europe probably via the branch 


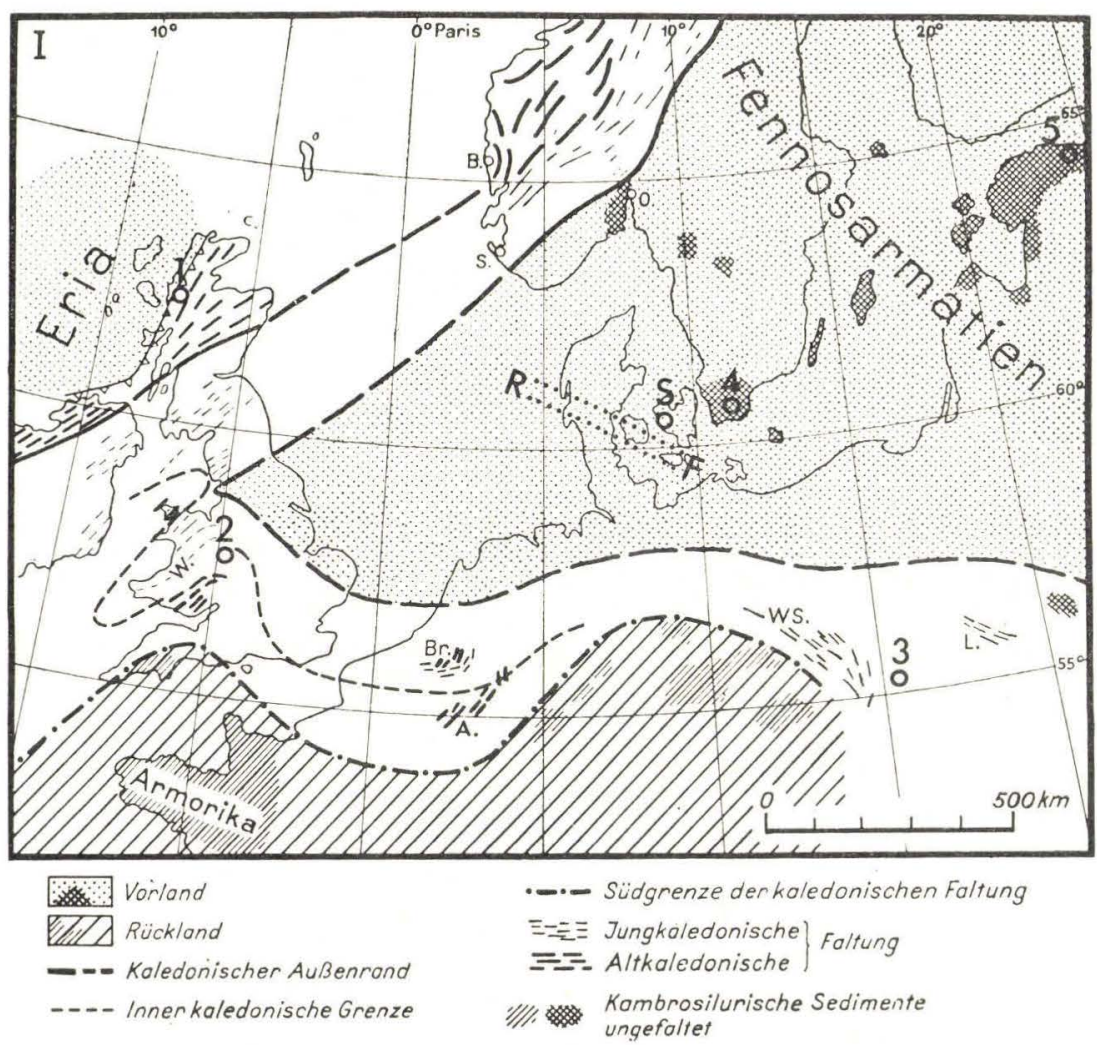

Fig. 2. Gaertner's map (fig. 1) of 1960 with added numbers and letters to show European occurences of the trilobite genus Wanneria (1-5), the Slagelse locality (S), and the subterranean Precambrian Ringkøbing-Funen gneiss ridge (RF). 1: Wanneria nathorsti Poulsen in the fucoid-beds of north-western Scotland. 2: Wanneria pennapyga RAw in the Green Callavia Sandstone $\left(\mathrm{Ac}_{1}\right)$ of Comley, Shropshire. 3: Wanneria cf. walcottana (WANNER) in grey arenaceous shale north of Görlitz, Upper Lusatia (Protolenus beds). 4: Wanneria lundgreni (Moberg) in sandstone at Tunbyholm, Scania. 5: Wanneria sp. in sandstone at Ziegelskoppel, Esthonia.

of the Caledonian geosyncline which extends eastward from England along the southern border of the East European platform (fig. 2). It is important in this connection that in the Holmia kjerulfi beds, known from Norway. Sweden, Denmark (Slagelse), and Poland, the genus Wanneria has never been found. For this reason the writer is of opinion that the Ringkøbing-Funen ridge may have been effective as part of a barrier during the deposition of the Holmia kjerulfi beds. This theory is in accordance with the fact that the Holmia kjerulfi fauna has never been found west or south-west of the Ringkøbing-Funen ridge; it should also be noticed that in Scania and Esthonia Wanneria is found in strata older than the Holmia kjerulfi beds, 
and that in Upper Lusatia this genus occurs in younger strata, associated with Lusatiops lusaticus (SchwarzBach 1934). The nature of the Ringkøbing-Funen ridge is unknown, but it is approximately parallel to the so-called Törnquist line (TörNQUIST 1910) i. e. parallel to the Scanian horst system, and, accordingly, the ridge may be interpreted as a horst. At Glamsbjerg on the island of Funen the present level of the ridge is about $-830 \mathrm{~m}$ i. e. a little more than $2000 \mathrm{~m}$ above the top of the Lower Cambrian of western Seeland (Slagelse). The tilting of the Prepermian beds at Slagelse may be a result of Caledonian or Variscan tectonic activity, as pointed out by Sorgenfrei \& Buch (1964). 


\title{
DANSK SAMMENDRAG
}

\author{
NEDRE KAMBRIUM I SLAGELSE NO. 1, VESTSJ ÆLLAND
}

Materialet, som danner grundlaget for den foreliggende afhandling, stammer fra en dybdeboring i nærheden af Slagelse. Boringen, der betegnes som Slagelse $n r .1$ (D.G.U. arkiv nr. 215.257), nåede ned til en dybde af $2972 \mathrm{~m}$ under terrænkoten. Boreprofilet er i sin helhed beskrevet af SoRGENFREI \& BuCH (1964).

De nederste lag er en kvartsitisk sandsten (Slagelse kvartsit). Borearbejdet blev standset, da boret var trængt $6 \mathrm{~m}$ ned i kvartsiten, hvis mægtighed således er ukendt.

Over Slagelse kvartsiten følger 22 m mørkegrå, hård skifret siltsten, hvori det lykkedes forfatteren at finde følgende nedre-kambriske fossiler:

Parahyolithes danicus n. g. et n. sp.

Kjerulfia selandica n. sp.

Holmi kjerulfi (LinNARSSON)?

Ellipsostrenua conifrons n. sp.

Torellella holmi KIÆR

Torellella laevigata (LinNARSSON)

ubestemmelige olenellidefragmenter.

På grundlag af denne fauna henføres aflejringen til zonen med Holmia kjerulfi.

Den underliggende Slagelse kvartsit viser i petrografisk henseende særdeles god overensstemmelse med Balka kvartsiten på Bornholm og henføres ligesom denne til zonen med Mobergella holsti. Slagelse kvartsitens kvartskorn antages at hidrøre fra forvitring af den underjordiske gneisryg, der strækker sig fra Ringkøbingegnen til Fyn. Dette grundfjeldsområde synes at have spillet en betydelig rolle i palæogeografisk henseende allerede i ældre Kambrium. Slagelse kvartsitens dannelse forudsætter tilstedeværelsen af en prækambrisk landoverflade, bestående af forvitrende gneis eller granit. Ringkøbing-Fyn-ryggen har formentlig allerede i ældre Kambrium udgjort en del af det danske sænkningsområdes vestlige kyst, og har således i det tidsrum, da Holmia kjerulfi-lagene blev aflejret, fungeret som del af en barriere, der har bidraget til at give basinet dets isolerede karakter. Den geografiske udbredelse af trilobitslægten Wanneria peger i samme retning. Denne slægt, hvis typiske forekomst er den appalachiske geosynklinal, Øst- og Nordgrønland, har formået at udbrede sig langt mod фst via den gren af den cale- 
doniske geosynklinal, som strækker sig fra England til Polen (fig. 2, side 22). Det er bemærkelsesværdigt, at de europæiske forekomster af Wanneria i dette geosynklinalområde er knyttet til lag, som er ældre eller yngre end Holmia kjerulfi-lagene; slægten er aldrig truffet i selve Holmia kjerulfi-faunaen. Disse forhold kan efter forfatterens mening tyde på, at Ringkøbing-Fyn-ryggen som del af en barriere har medvirket til at isolere Holmia kjerulfi-basinet og forhindre invasion af Wanneria. I denne forbindelse må også nævnes, at Holmia kjerulfi-faunaen er ganske ukendt vest og sydvest for ryggen.

Ringk $\emptyset$ bing-Fyn-ryggens natur er ukendt, men den omstændighed, at den er tilnærmelsesvis parallel med det skånske system af grundfjeldshorste leder tanken hen på den mulighed, at der her er tale om en horst.

Som nævnt af Sorgenfrei \& Buch (1964) kan de ældre palæozoiske lags hældning ved Slagelse skyldes caledoniske eller variskiske jordskorpebevægelser. 


\section{REFERENCES}

CZARnockI, J., 1927. Le cambrien et la faune cambrienne de la partie moyenne du massif de Swiety Krzyz. - C.-R. 15e Congr. Géol. Intern. 1926. - Madrid.

Fisher, D. W., 1962. Small Conoidal Shells of Uncertain Affinities. - Treatise on Invertebrate Paleontology, part W, Miscellanea. - Lawrence, Kansas.

Gaertner, H. R. von, 1960. Über die Verbindung der Bruchstïcke des Kaledonischen Gebirges im Nördlichen Mitteleuropa. - Intern. Geol. Congr., Report of the Twenty-First Session Norden, part 19, Caledonian Orogeny. - Copenhagen.

Holm, G., 1893. Sveriges Kambrisk-Siluriska Hyolithidae och Conulariidae. - Sveriges Geologiska Undersökning, ser. C, no. 112. - Stockholm.

JAnischewsky, M., 1927. Ueber Trilobitenreste (Schmidtiellus Mickwitzi F. Schm.) aus dem kambrischen blauen Ton. - Annuaire Soc. Paléont. Russie, 6, p. 25-50. Leningrad.

KaUtsky, F., 1945. Die unterkambrische Fauna von Aistjakk in Lappland. - Geologiska Föreningens i Stockholm Förhandlingar, Bd. 67, Hft. 2.

KIÆR, J., 1916. The Lower Cambrian Holmia Fauna at Tømten in Norway. - Videnskapsselskapets Skrifter, I, Matematisk-naturvidenskapelig Klasse, no. 10. - Christiania.

MoberG, J. C., 1899. Sveriges äldsta kända trilobiter. - Geologiska Föreningens i Stockholm Förhandlingar, Bd. 21, Hft. 4, p. 309-348.

Poulsen, C., 1951. The position of the East Greenland Cambro-Ordovician in the Palaeogeography of the North-Atlantic Region. - Meddelelser Dansk Geologisk Forening, Bd. 12, Hft. 1. - Copenhagen.

- 1958. Contribution to the Palaeontology of the Lower Cambrian Wulff River Formation. - Meddelelser om Grønland, vol. 162, no. 2. - Copenhagen.

- V., 1963. Notes on Hyolithellus Brlinngs, 1871, Class Pogonophora Johansson, 1937. - Biologiske Meddelelser, Kgl. Danske Videnskabernes Selskab, Bd. 23, no. 12. - Copenhagen.

Raw, F., 1936. Mesonacidae of Comley in Shropshire, with a Discussion of the Classificaton within the Family. - Quart. Journ. Geol. Soc. of London, vol. 92, p. 236-293.

Samsonowicz, J., 1956. Cambrian Paleogeography and the Base of the Cambrian System in Poland. - Symposium. - 20th Intern. Geol. Congr. - Mexico.

- 1959. On the Holmia-fauna in the Cambrian of the Anticlinorium of Klimontów. Ibidem, 7, 7.

- 1960. The Lower Cambrian of the Klimontów Anticlinorium. - Intern. Geol. Congr., Report of the Twenty-First Session Norden, part 8, Late Pre-Cambrian and Cambrian Stratigraphy. - Copenhagen.

Schindewolf, H., 1927. Über Holmia mickwitzi Schm. - Zeitschr. d. deutsch. Geol. Gesellsch., Bd. 79. - Berlin.

Schmid, F., 1888. Ueber eine neuentdeckte unterkambrische Fauna in Estland. Mém. de l'Acad. Imp. des Sciences de St. Pétersbourg, Ser. 7, Tome 36, no. 2.

SchwarzBach, M., 1939. Die Oberlausitzer Protolenus-fauna. - Jahrbuch d. Preussischen Geologischen Landesanstalt für 1938. - Berlin. 
Sorgenfrei, Th. \& Buch, A., 1964. Deep Tests in Denmark 1935-1959. - Danmarks Geologiske Unders $\varnothing$ gelse, 3. Række, no. 36. - Copenhagen.

Størmer, L., 1967. Some aspects of the Caledonian geosyncline and foreland west of the Baltic Shield. - Quart. Journ. Geol. Soc. of London, vol. 123, p. 183-214.

Törnquist, A., 1910. Geologie von Ostpreussen. - Berlin.

Walcott, C. D., 1910. Olenellus and other Genera of the Mesonacidae. - Smithsonian Miscellaneous Collections, vol. 53, no. 6. - Washington, D. C.

ÖPIK, A., 1925. Beitrag zur Stratigraphie und Fauna des estnischen Unter-Kambriums (Eophyton-Sandstein). - Publ, of the Geol. Inst. of the Univ. of Tartu. 


\section{EXPLANATION OF PLATE}

Fig. 1-2. Kjerulfia selandica n. sp.

- 1. Fragmentary cephalon (holotype), $\times 2$.

- 2. Cast of external mould of the same, furnishing supplementary information, $\times 2$.

- 3. Holmia kjerulfi (Linnarsson) ? Fragment of cephalon (cast of external

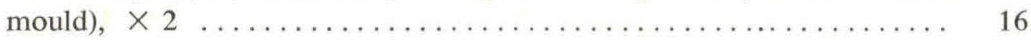

- 4-5. Undetermined olenellid

4. Fragment of large cephalon, $\times 1$.

- 5. Cast of external mould of the same, furnishing supplementary information, $\times 1$.

- 6-7. Ellipsostrenua conifrons n. sp.

- 6. Slightly deformed cranidium (holotype), $\times 2$.

- 7. Cast of external mould of the same, furnishing supplementary information, $\times 2$.

- 8. Parahyolithes danicus n. g. et n. sp. (holotype), ventral side, $\times 4 \ldots$

- 9. Torellella holmi KIER, small, almost complete shell, $\times 4$ 


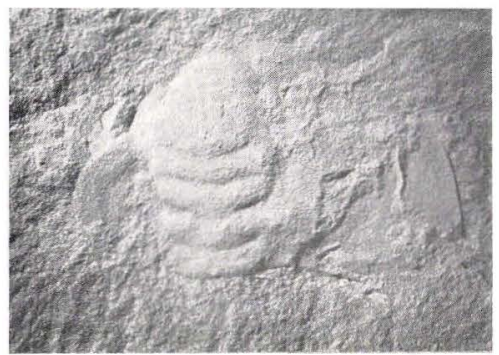

1

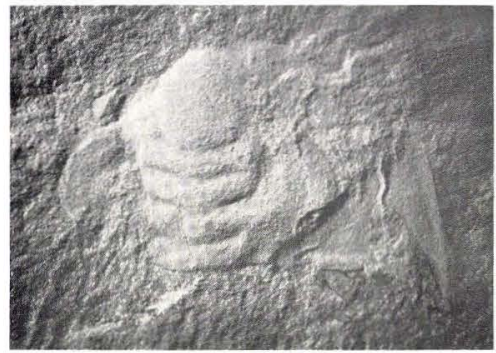

2

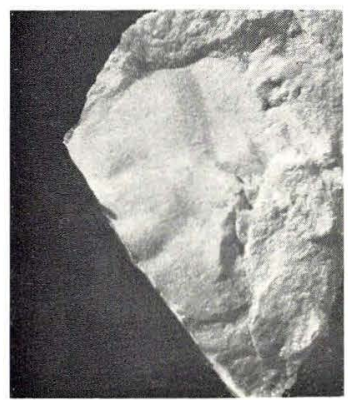

3

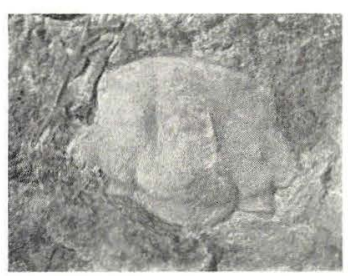

6

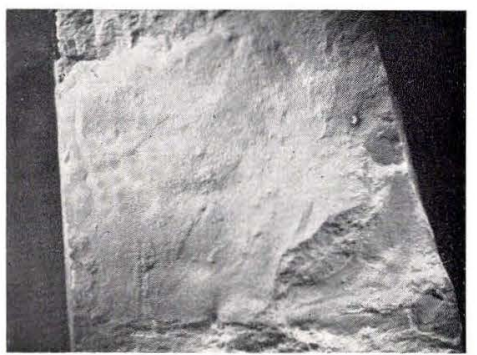

4

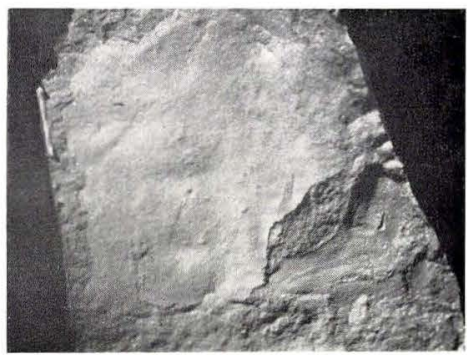

5

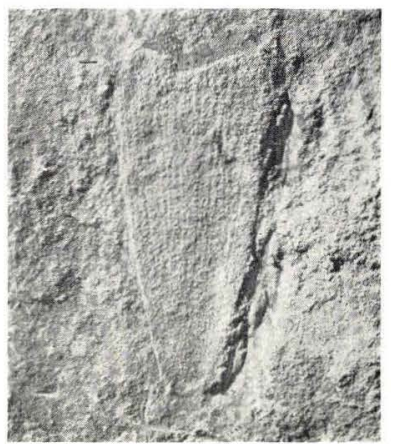

8

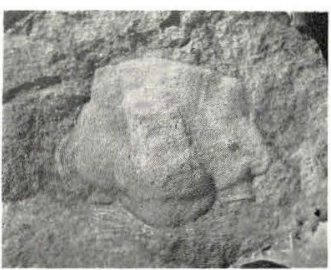

7 
